\title{
Prestasi Belajar Bahasa Indonesia: Pengaruh Minat Belajar dan Motivasi Belajar
}

\author{
Warsadi \\ Universitas Indraprasta PGRI \\ Jalan Nangka No. 58 C/TB. Simatupang, Tanjung Barat, Jakarta Selatan 12530 \\ ediwarsa@gmail.com
}

\begin{abstract}
This study aims to determine the effect of learning interest and learning motivation on learning achievement in Indonesian. This study uses survey methods, with a population of 916 State Junior High Schools in Bogor City. By using a proportional random sampling technique obtained a sample of 90 students. Data were obtained from questionnaires and Indonesian learning achievement tests and analysed with SPSS 20. The results of this study prove that interest in learning and motivation to learn contribute to learning achievement in Indonesian.
\end{abstract}

Keywords: Indonesian language learning achievement, interest in learning, and learning motivation.

\begin{abstract}
Abstrak
Penelitian ini bertujuan untuk mengetahui pengaruh minat belajar dan motivasi belajar terhadap prestasi belajar Bahasa Indonesia. Penelitian ini menggunakan metode survei, dengan populasi siswa SMP Negeri di Kota Bogor sejumlah 916. Dengan menggunakan teknik sampling acak proporsional diperoleh sampel sebanyak 90 siswa. Data diperoleh dari kuesioner dan tes Prestasi belajar Bahasa Indonesia dan dianalisis dengan SPSS 20. Hasil penelitian ini membuktikan bahwa minat belajar dan motivasi belajar berkontribusi terhadap prestasi belajar Bahasa Indonesia.
\end{abstract}

Kata Kunci: prestasi belajar bahasa Indonesia, minat belajar, dan motivasi belajar

\section{PENDAHULUAN}

Pendidikan adalah usaha sadar untuk menumbuhkembangkan Sumber Daya Manusia (SDM) melalui kegiatan belajar. Melalui kegiatan belajar diharapkan akan tercapai tujuan pendidikan. Kegiatan belajar mengajar ini kemudian akan menghasilkan sesuatu yang pada umumnya disebut sebagai hasil pembelajaran. Parameter yang digunakan untuk mengukur tingkat keberhasilan pendidikan adalah prestasi belajar.

Winkel (2004:53) mengatakan bahwa belajar adalah perubahan tingkah laku karena suatu pengalaman atau latihan yang berlangsung selama kurun waktu, bukan perubahan tingkah laku karena pertumbuhan, pematangan maupun perubahan fisik. Perubahan perilaku ini harus bersifat relatif konstan dan berbekas.

Syah (2001:91) menyatakan bahwa belajar dapat dipahami sebagai bagian perubahan sebuah tingkah laku individu yang relatif menetap sebagai hasil pengalaman dari hasil pengalaman dari interaksi dengan lingkungan yang mengharuskan proses kognitif.

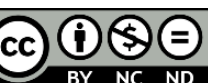

Creative Commons Attribution-NonCommercial-NoDerivatives 4.0 International License 
Definisi belajar dapat ditinjau dari sudut pandangan kuantitatif, institusional dan kualitatif secara kuantitatif, belajar berarti kegiatan pengisian atau pengembangan kemampuan kognitif dengan fakta sebanyak-banyaknya. Jadi belajar dalam hal ini dipandang dari sudut berapa banyak materi yang dikuasai siswa.

Nawawi (2005: 128) mengemukakan bahwa hasil belajar merupakan tingkat keberhasilan dalam mempelajari materi pelajaran tertentu sebagai perwujudan aktivitas yang dilakukan siswa sebagai proses belajar yang dapat dinyatakan dalam bentuk skor.

Berdasarkan beberapa teori belajar dapat dinyatakan bahwa pencapaian tujuan pembelajaran oleh siswa disebut juga prestasi belajar. Prestasi belajar siswa berupa pengetahuan, keterampilan, serta nilai dan sikap yang diperoleh seseorang setelah mengikuti kegiatan belajar mengajar. Hasil belajar ini dapat diukur setelah siswa mengikuti semua hasil kegiatan pembelajaran tes hasil belajar.

Siswa yang berhasil dalam proses belajar mengajar dapat dilihat dari hasil belajarnya yang tinggi, sedangkan yang kurang berhasil adalah siswa yang hasil belajarnya rendah.

Prestasi belajar merupakan masalah yang sangat penting bagi siswa maupun bagi pendidik. Prestasi belajar yang baik adalah keinginan yang dicita-citakan oleh setiap siswa maupun pendidik. Oleh karena itu yang merupakan tolak ukur keberhasilan proses belajar mengajar adalah prestasi belajar siswa. Apabila prestasi siswa baik, maka dapat dikatakan proses pengajaran oleh pendidik berhasil baik, tetapi jika prestasi belajar yang dicapai siswa rendah, maka dapat dikatakan bahwa pengajaran yang dilakukan oleh guru belum berhasil dengan baik.

. Keberhasilan proses belajar dapat dilihat dari nilai-nilai siswa pada setiap mata pelajaran yang pada kenyataannya sangat bervariasi, rendah sedang dan tinggi. Banyak faktor yang menyebabkan prestasi hasil belajar Bahasa Indonesia siswa rendah yaitu faktor internal dan eksternal dari siswa. Salah satu faktor internal yang mempunyai peranan penting dalam mempengaruhi prestasi belajar siswa adalah minat.

Menurut DePoler dan Hemackhi (2002:51) bahwa menciptakan minat adalah cara-cara yang sangat baik untuk memberikan motivasi pada diri untuk mencapai tujuan.

Menurut Slameto (2003:57), minat adalah suatu rasa lebih suka dan rasa ketertarikan pada suatu hal atau aktivitas, tanpa ada yang menyuruh. Minat pada dasarnya adalah penerimaan akan suatu hubungan antara diri sendiri sesuatu di luar diri. Semakin kuat hubungan tersebut semakin kuat minat.

Minat adalah kecenderungan yang tetap untuk memperhatikan dan mengenang beberapa kegiatan. Kegiatan yang diminati seseorang diperhatikan terus menerus yang disertai dengan rasa senang. Minat berbeda dengan perhatian karena perhatian sifatnya sementara (tidak dalam waktu yang lama) dan belum tentu diikuti dengan perasaan senang dan dari situ diperoleh keputusan.

Minat terjadi dalam kesempatan pertama yang menimbulkan keinginan tulisan yang kuat oleh siswa,

When teacher we this fromework for intruktional planning, school experiences first engage leaner in a topic, just as the child in our scenario was 
angaged Engagement piques curiosity driving investigation of the topic (Dever and Deborah E Hobbs, 2000:131)

Dari pengertian di atas disimpulkan bahwa minat belajar adalah sesuatu yang membangkitkan atau mendorong seseorang untuk menjadi giat belajar dalam mencapai cita-cita yang ia inginkan berusaha untuk mengetahui suatu pelajaran dengan cara mengetahui, mengikuti, memahami pelajaran, memusatkan perhatian belajar lebih giat dan waktunya mencapai prestasi yang ditingkatkan minat belajar akan memberikan melahirkan perhatian memudahkan terciptanya konsentrasi mencegah gangguan perhatian dari luar, memperkuat melekatnya bahan pelajaran dalam ingatan, memperkecil kebosanan studi dalam diri sendiri.

Minat belajar Bahasa Indonesia merupakan kondisi psikologis dalam diri manusia yang dapat meningkatkan gairah siswa dan menyebabkan ia menggunakan waktu, energi, perhatian, dorongan, kreativitas untuk mencapai cita-cita dalam bidang bahasa

Selain minat, keberhasilan siswa dalam belajar juga dipengaruhi oleh, faktor lain yang juga tidak kalah penting yaitu motivasi belajar.

Menurut Rasyad (2003:89) dikemukakan bahwa "motif" (motive), berasal dari bahasa latin motivasi atau motive, yang berarti segala sesuatu yang mendorong seseorang untuk berbuat atau bertindak melakukan sesuatu kegiatan untuk mencapai tujuan.

Motivasi adalah kekuatan dari dalam yang menggerakkan dan mengarahkan atau membawa tingkah laku ke tujuan (Gunarsa, 2004:20). Motif berkaita erat dengan suatu tujuan, cita-cita, dan harapan. Makin berharga dan tinggi suatu tujuan, maka makin kuat motifnya. Dari beberapa pendapat di atas motivasi dirangkum menjadi sesuatu yang timbul pada diri seseorang secara sadar atau tidak sadar dan mendorong seseorang untuk berbuat atau bertindak karena ada factor pendukung yakni motif dari dalam dirinya untuk melakukan suatu kegiatan.

Motivasi belajar adalah suatu dorongan yang ada pada seseorang sehubungan dengan prestasi, yaitu dorongan untuk menguasai, mengevaluasi serta mengatur lingkungan sosial maupun fisik, mengatasi rintangan-rintangan dan memelihara kualitas kerja yang tinggi, bersaing melalui usaha-usaha untuk melebihi perbuatan di masa lalu serta untuk mengungguli perbuatan orang lain.

Seorang individu dengan tingkat motivasi belajar yang tinggi juga kecenderungan untuk mempunyai tingkat kepercayaan diri yang tinggi, mempunyai tanggung jawab dan selalu berusaha untuk memperoleh nilai yang baik, aktif dalam kehidupan sosial, dalam memilih teman cenderung memilih teman yang ahli daripada seorang sahabat, serta tahan dengan tekanan-tekanan yang ada dalam masyarakat.

Perwujudan dari motivasi belajar yang tinggi dalam bentuk tingkah laku berorientasi pada pencapaian prestasi. Motivasi belajar Bahasa Indonesia adalah dorongan yang datang dari dalam diri seseorang untuk bergerak atau melakukan aktivitas belajar bahasa.

Penelitian ini bertujuan untuk mengetahui:1) Apakah terdapat pengaruh minat dan motivasi belajar secara bersama-sama terhadap prestasi belajar Bahasa Indonesia siswa SMP Negeri Kota Bogor?, 2)Apakah terdapat pengaruh minat belajar terhadap prestasi belajar Bahasa Indonesia siswa SMP Negeri Kota Bogor?,

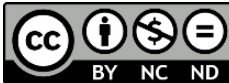


dan 3) Apakah terdapat pengaruh motivasi belajar terhadap prestasi belajar Bahasa Indonesia siswa SMP Negeri Kota Bogor?

\section{METODE}

Metode yang digunakan dalam penelitian ini adalah metode survei dengan analisis korelasi regresi ganda. Penelitian ini dilaksanakan pada tiga Sekolah Menengah Pertama Negeri di Kota Bogor, yaitu: SMPN 5, SMPN 8, dan SMPN 12 Bogor. Dengan jumlah populasi 916 siswa dan jumlah sampel 90 siswa. Data dalam penelitian ini diperoleh berdasarkan tes prestasi belajar Bahasa Indonesia siswa serta pemberian angket minat belajar dan motivasi belajar.

Variabel Prestasi Belajar Bahasa Indonesia merupakan perubahanperubahan yang dihasilkan setelah melalui proses belajar, yang meliputi perubahan dalam pengetahuan, pemahaman keterampilan dan nilai sikap dalam pembelajaran Mata Pelajaran Bahasa Indonesia, yang bersifat konstan/menetap. Indikator dari variabel ini adalah skor yang didapatkan siswa dengan alat ukur berupa seperangkat tes yang berpedoman pada Kompetensi Dasar yang harus dikuasai siswa kelas VII yang terdapat dalam Peraturan Menteri Pendidikan dan Kebudayaan Republik Indonesia Nomor 24 Tahun 2016 Tentang Kompetensi Inti dan Kompetensi Dasar Pelajaran Pada Kurikulum 2013 Pada Pendidikan Dasar dan Pendidikan Menengah.

Variabel Minat belajar bahasa Indonesia merupakan kondisi psikologis dalam diri manusia yang dapat membangkitkan gairah siswa dan menyebabkan ia menggunakan waktu, energi, perhatian, dorongan, kreativitas untuk mencapai citacita yang terkait dengan konsep-konsep dasar Bahasa Indonesia. Siswa yang memiliki minat belajar Bahasa Indonesia akan cenderung berusaha untuk lebih aktif belajar, selalu berusaha memahami konsep dan prinsip objek Bahasa Indonesia yang dipelajari dengan indikator: 1. Perhatian, 2. Dorongan, 3. Keaktifan, 4. Citacita.

Variabel Motivasi belajar bahasa Indonesia adalah dorongan yang datang dalam diri seseorang untuk bergerak atau melakukan aktivitas belajar bahasa Indonesia yang digambarkan melalui indikator-indikator, yaitu : 1. Memiliki inisiatif untuk belajar Bahasa Indonesia, 2. Belajar bahasa Indonesia dengan sungguh-sungguh, 3. Berusaha melengkapi alat-alat pelajaran, 4. Mengerjakan tugas belajar tepat waktu, 5. Bertanya bila pelajaran kurang jelas atau dimengerti, 6. Melatih diri dalam menjawab soal-soal, 7. Rajin ke sekolah, 8. Memiliki target nilai, 9. Memiliki jadwal pelajaran, 10. Disiplin dalam melaksanakan tugas pelajaran.

Pengujian pengaruh Minat Belajar dan Motivasi Belajar terhadap Prestasi Belajar Bahasa Indonesia siswa dilakukan dengan mengajukan dan menguji sejumlah hipotesis.

Setelah instrumen seluruh variabel melalui uji validitas dan reliabilitas, didapatkan 30 butir instrumen variable Minat Belajar, 33 butir untuk variabel Motivasi belajar, dan 33 Butir instrumen untuk variabel Prestasi belajar Bahasa Indonesia. 


\section{HASIL DAN PEMBAHASAN}

Hasil penelitian ini telah melalui uji persyaratan analisis. Pertama uji normalitas terhadap seluruh variabel. Dengan batuan SPSS 20, menunjukkan bahwa semua sampel pada penelitian ini berdistribusi normal hal ini ditunjukkan dengan nilai-nilai pada kolom Sig pada metode Kolmogorov-Smirnov untuk semua sampel lebih besar dari 0,05. Dalam uji Normalitas Galat menunjukkan Sig 0,852 > 0,05, maka persyaratan analisis regresi terpenuhi.

Berdasarkan kriteria statistic tolerance (TOL) yang menyatakan bahwa variabel bebas dinyatakan tidak multikolinearitas apabila nilai TOL $>0,1(10 \%)$ dan nilai variance inflaction factor $(\mathrm{VIF})<10$. Hasil uji multikolinearitas pada tabel diketahui bahwa hasil TOL 0,659 > 0,1 dan VIF = 1,518<10 Sehingga dapat dinyatakan tidak ada multikolinearitas antara Minat Baca dan Motivasi Belajar pada analisis regresi ganda ini.

Selanjutnya dilakukan uji linearitas untuk menentukan teknik dan analisis regresi apakah variabel bebas $\left(\mathrm{X}_{1}\right.$ dan $\left.\mathrm{X}_{2}\right)$ dan variabel terikat $(\mathrm{Y})$ terbentuk linear. Dengan bantuan SPSS 20 didapatkan hasil sebagai berikut, uji linearitas hubungan variabel $\mathrm{X}_{1}$ dan $\mathrm{Y}$. Didapatkan nilai $\mathrm{F}_{\mathrm{h}}=0,833$ dan Sig. $=0,771>0,05$, sehingga $\mathrm{H}_{0}$ diterima, dengan kata lain bahwa garis regresi hubungan antara varibel $\mathrm{X}_{1}$ dan variabel $\mathrm{Y}$ adalah linier. Uji linearitas hubungan variabel $\mathrm{X}_{2}$ dan $\mathrm{Y}$ didapatkan nilai $\mathrm{F}_{\mathrm{h}}=1,439$ dan $\mathrm{Sig}=0,121>0,05$, sehingga $\mathrm{H}_{0}$ diterima, dengan kata lain bahwa garis regresi hubungan antara varibel $\mathrm{X}_{2}$ dan variabel $\mathrm{Y}$ adalah linier.

Uji hipotesis penelitian tersaji dalam tabel berikut:

\section{Tabel 1. Rekapitulasi Hasil Perhitungan Koefisien Korelasi Pengaruh Variabel $X_{1}$ dan $X_{2}$ terhadap Variabel Y}

Model Summary

\begin{tabular}{|l|r|r|r|rr|}
\hline Model & R & R Square & $\begin{array}{c}\text { Adjusted R } \\
\text { Square }\end{array}$ & \multicolumn{2}{|c|}{$\begin{array}{c}\text { Std. Error of the } \\
\text { Estimate }\end{array}$} \\
\hline 1 & $.726^{\mathrm{a}}$ & .526 & .516 & 6.880 \\
\hline
\end{tabular}

a. Predictors: (Constant), Motivasi Belajar, Minat Belajar

Tabel 2. Rekapitulasi Hasil Perhitungan Persamaan Garis Regresi Pengaruh Variabel $\mathbf{X}_{1}$ dan $\mathbf{X}_{2}$ terhadap Variabel $Y$

ANOVA ${ }^{a}$

\begin{tabular}{|l|c|r|r|r|r|}
\hline Model & $\begin{array}{c}\text { Sum of } \\
\text { Squares }\end{array}$ & df & Mean Square & F & Sig. \\
\hline Regression & 4577.213 & 2 & 2288.606 & 48.355 & $.000^{\mathrm{b}}$ \\
1 Residual & 4117.687 & 87 & 47.330 & & \\
$\quad$ Total & 8694.900 & 89 & & & \\
\hline
\end{tabular}

a. Dependent Variable: Prestasi Belajar Bahasa Indonesia

b. Predictors: (Constant), Motivasi Belajar, Minat Belajar 
Tabel 3. Coefficientsa

Coefficientsa

\begin{tabular}{|c|c|c|c|c|c|c|}
\hline \multirow{2}{*}{\multicolumn{2}{|c|}{ Model }} & \multicolumn{2}{|c|}{$\begin{array}{l}\text { Unstandardized } \\
\text { Coefficients }\end{array}$} & $\begin{array}{c}\text { Standardized } \\
\text { Coefficients }\end{array}$ & \multirow[t]{2}{*}{$\mathrm{t}$} & \multirow[t]{2}{*}{ Sig. } \\
\hline & & B & $\begin{array}{l}\text { Std. } \\
\text { Error }\end{array}$ & Beta & & \\
\hline \multirow{3}{*}{1} & (Constant) & -25.646 & 11.390 & & -2.252 & .027 \\
\hline & $\begin{array}{l}\text { Minat } \\
\text { Belajar }\end{array}$ & .512 & .089 & .522 & 5.745 & .000 \\
\hline & $\begin{array}{l}\text { Motivasi } \\
\text { Belajar }\end{array}$ & .344 & .110 & .284 & 3.122 & .002 \\
\hline
\end{tabular}

a. Dependent Variable: Prestasi Belajar Bahasa Indonesia

\section{Pengaruh Minat Belajar dan Motivasi Belajar secara bersama-sama terhadap Prestasi belajar Bahasa Indonesia}

Dari deskriptif data setelah dilakukan analisis korelasi diperoleh koefisien korelasi sebesar 0,726. Hal ini berarti bahwa terdapat pengaruh variabel bebas $\mathrm{X}_{1}$ (Minat Belajar) dan $\mathrm{X}_{2}$ (Motivasi Belajar) secara bersama-sama terhadap variabel terikat Y (Prestasi Belajar Bahasa Indonesia).

Sedangkan dari analisis regresi diperoleh persamaan garis regresi $\mathrm{Y} \cong$ 0,512 $\mathrm{X}_{1}+0,344 \mathrm{X}_{2}-25,646$ Nilai konstanta $=-25,646$ menunjukkan bahwa siswa dengan Minat Belajar dan Motivasi Belajar paling rendah sulit untuk bisa mendapatkan prestasi belajar Bahasa Indonesia yang baik, sedangkan nilai koefisien regresi sebesar 0,512 dan 0,344 menunjukkan bahwa terdapat pengaruh positif variabel bebas $X_{1}$ (Minat Belajar) dan pengaruh positif $X_{2}$ (Motivasi Belajar) secara bersama-sama terhadap variabel terikat $\mathrm{Y}$

(Prestasi Belajar Bahasa Indonesia). Setelah dilakukan pengujian linieritas garis regresi dengan menggunakan program SPSS diperoleh bahwa garis regresi tersebut linier.

Dari pengujian signifikansi koefisien regresi yang juga dilakukan dengan program SPSS diperoleh bahwa koefisien regresi tersebut signifikan, yaitu ditunjukkan oleh nilai $\mathrm{Sig}=0,000<0,05$ dan $\mathrm{F}_{\mathrm{h}}=48,355$ maka regresi tersebut signifikan, yang berarti benar bahwa terdapat pengaruh yang positif variabel bebas $\mathrm{X}_{1}$ ( Minat Belajar) dan $\mathrm{X}_{2}$ (Motivasi Belajar) secara bersama-sama terhadap variabel terikat Y (Prestasi Belajar Bahasa Indonesia).

Minat Belajar yang positif dan sehat akan melahirkan motivasi belajar yang tinggi. Motivasi belajar yang kuat akan menjadi landasan yang kuat bagi siswa untuk memiliki prestasi belajar Bahasa Indonesia yang lebih tinggi.

Peranan minat dalam belajar adalah sebagai monivating force yaitu sebagai kekuatan yang akan mendorong siswa untuk belajar. Siswa yang berminat (sikapnya senang) kepada pelajaran akan tampak terdorong terus untuk tekun belajar. Minat belajar Bahasa Indonesia merupakan kondisi psikologis dalam diri manusia yang dapat meningkatkan gairah siswa dan menyebabkan ia menggunakan waktu, energi, perhatian, dorongan, kreativitas untuk mencapai cita-cita dalam 
bidang bahasa. Siswa yang memiliki minat ia akan cenderung berusaha untuk lebih aktif,

Motivasi Belajar tidak hanya bermakna bagi proses belajar siswa, tetapi juga memberikan umpan balik bagi pencapaian tujuan-tujuan yang diharapkan. Selain itu dapat digunakan untuk mengukur sampai sejauh mana keefektifan pengalaman belajar siswa. Berdasarkan temuan ini menunjukkan bahwa peningkatan prestasi belajar Bahasa Indonesia dapat dilakukan dengan Minat Belajar dan Motivasi Belajar. Dengan kata lain, penelitian ini menunjukkan bahwa adanya peningkatan Prestasi Belajar Bahasa Indonesia secara bersama-sama oleh Minat Belajar dan Motivasi Belajar.

\section{Pengaruh Minat Belajar terhadap Prestasi Belajar Bahasa Indonesia}

Dari pengujian hipotesis diperoleh bahwa nilai $\operatorname{Sig}=0,000<0,05$ dan $t_{\text {hitung }}=5,745$ maka $\mathrm{H}_{0}$ ditolak yang berarti terdapat pengaruh yang signifikan variabel bebas $\mathrm{X}_{1}$ (minat belajar) terhadap variabel terikat Y (prestasi belajar Bahasa Indonesia).

Hal ini sejalan dengan pendapat Hobbs

When teacher we this fromework for intruktional planning, school experiences first engage leaner in a topic, just as the child in our scenario was angaged Engagement piques curiosity driving investigation of the topic (Dever and Deborah E Hobbs, 2000:131)

Dari pengertian di atas disimpulkan bahwa minat belajar adalah sesuatu yang membangkitkan atau mendorong seseorang untuk menjadi giat belajar dalam mencapai cita-cita yang ia inginkan berusaha untuk mengetahui suatu pelajaran dengan cara mengetahui, mengikuti, memahami pelajaran, memusatkan perhatian belajar lebih giat dan mencapai prestasi yang ditingkatkan minat belajar akan memberikan melahirkan perhatian memudahkan terciptanya konsentrasi mencegah gangguan perhatian dari luar, memperkuat melekatnya bahan pelajaran dalam ingatan, memperkecil kebosanan studi dalam diri sendiri, dan akhirnya mencapai prestasi yang tinggi.

\section{Pengaruh Motivasi Belajar Terhadap Prestasi Belajar Bahasa Indonesia.}

Dari pengujian hipotesis diperoleh bahwa nilai Sig $=0,000<0,05$ dan $t_{\text {hitung }}$ = 3,122 maka $\mathrm{H}_{0}$ ditolak yang berarti terdapat pengaruh yang signifikan variabel bebas $\mathrm{X}_{2}$ (Motivasi Belajar) terhadap variabel terikat Y (Prestasi Belajar Bahasa Indonesia). Hal ini sejalan dengan pendapat Wina (2008: 251-252) menyatakan bahwa pembelajaran akan berhasil jika siswa memiliki motivasi dalam belajar.

Motivasi belajar merupakan kondisi psikologis yang mendorong siswa untuk belajar secara sungguh-sungguh. Motivasi belajar memiliki peranan yang sangat menentukan dan mendorong siswa untuk belajar dengan penuh perhatian dan konsentrasi dalam menerima pelajaran, sehingga tercapai tujuan yang diharapkan oleh siswa yaitu hasil belajarnya yang ditunjukkan dengan prestasi belajar akan meningkat. Jadi dalam hal ini motivasi belajar berpengaruh terhadap hasil belajar.

Semakin tinggi motivasi belajar, maka prestasi belajar yang dicapai akan semakin meningkat, sebaliknya semakin rendah motivasi belajar maka hasil belajar yang dicapai akan semakin menurun. Kemudian dalam hubungannya dengan 
kegiatan belajar, yang penting bagaimana menciptakan kondisi atau suatu proses yang mengarahkan siswa itu melakukan aktivitas belajar.

Guru harus melakukan usaha-usaha untuk dapat menumbuhkan dan memberikan motivasi agar anak didiknya melakukan aktivitas belajar dengan baik. Untuk dapat belajar dengan baik diperlukan proses dan motivasi yang baik pula.

Berdasarkan temuan penelitian telah dibuktikan bahwa terdapat pengaruh Motivasi Belajar terhadap prestasi belajar Bahasa Indonesia siswa SMP Negeri di Kota Bogor. Siswa yang memiliki Motivasi Belajar yang tinggi akan memiliki prestasi yang tinggi juga.

\section{SIMPULAN}

Prestasi belajar Bahasa Indonesia siswa SMP Negeri di Kota Bogor yang diteliti secara kausal dipengaruhi oleh variabel minat belajar dan motivasi belajar. Semakin baik minat belajar dan motivasi belajar siswa, maka akan lebih baik juga prestasi belajar Bahasa Indonesia yang diraih siswa.

Guru memiliki peran sentral dalam peningkatan prestasi belajar Bahasa Indonesia siswa, maka guru harus senantiasa memperhatikan pelbagai faktor yang memengaruhi prestasi belajar siswa, termasuk prestasi belajar Bahasa Indonesia. Beberapa faktor di antaranya adalah minat belajar dan motivasi belajar siswa. Guru harus lebih cerdas dan kreatif agar siswa selalu mempunyai minat belajar dan motivasi belajar yang tinggi.

Motivasi dapat berfungsi sebagai pendorong usaha dan pencapaian prestasi. Adanya motivasi yang baik dalam belajar akan menunjukkan hasil yang baik. Dengan kata lain, dengan adanya usaha yang tekun dan terutama didasari adanya motivasi, maka seseorang yang belajar itu akan dapat melahirkan prestasi yang baik. Intensitas motivasi seseorang akan sangat menentukan tingkat pencapaian prestasi belajarnya. Oleh karena itu, baik siswa, guru, maupun orang tua harus senantiasa menjaga agar siswa memiliki motivasi belajar yang tinggi. Salah satu usaha tersebut bisa dengan memberikan reward atau penghargaan kepada siswa.

Guru dan pelbagai pihak yang berperan dan bertanggung jawab dalam usaha pencapaian prestasi belajar siswa harus benar-benar memerhatikan minat belajar dan motivasi belajar siswa.

\section{DAFTAR PUSTAKA}

Ahmadi, A. (2003). Psikologi belajar. Jakarta Rineka Cipta

Angkowo, R., \& Ahmad, K. (2007). Operasionalisasi media pembelajaran. Jakarta. Grafindo.

Arikunto, S. (2010). Dasar-dasar evaluasi pendidikan. Jakarta PT. Bumi Aksara. Hamzah, B. U. (2008). Teori Motivasi dan Pengukurannya, Jakarta: PT. Bumi Aksara.

Crow D.L., \& Crow. A. (2005). Psikologi pendidikan. Penerjemah Rachman Abror Abd. Yogyakarta Nur Cahaya. 
Djaali. (2008). Psikologi pendidikan. Jakarta: Bumi Aksara.

Djaali., \& Purnomo, M. (2008). Pengukuran dalam bidang pendidikan. Jakarta: Grasindo.

Djamirah, S. B. (2002). Strategi belajar mengajar. Jakarta Rineka Cipta

DePorter, B., \& Hemackhi, M. (2002). Quantum learning membiasakan belajar nyaman dan menyenangkan. Jakarta Kaifa.

Dimyati, M. (2008). Belajar dan pembelajaran. Jakarta Rineka Cipta.

Gagne, R. M. (2001). The conditional of learning Florida Holt, Rienhart and Winstone

Hamalik, O. (2008). Proses belajar mengajar. Jakarta PT Bumi Aksara

Nawawi, H. (2003). Pengantar penelitian. Pendidikan Bandung Grafindo

Sudjana, N. (2004). Penilaian hasil proses belajar mengajar, Bandung PT/ Remaja Rosdakarya.

Nasution, S. (2005). Didakdik azas-azas mengajar. Bandung Penerbit Jamnas.

Purwanto, M. N. (2004). Psikologi pendidikan. Bandung PT. Remaja Rosdakarya

Purwanto, M. N. (2009). Prinsip-prinsip dan teknik evaluasi pengajaran. Bandung. PT. Remaja Rosdakarya.

Rasyad, A. (2003). Teori pembelajaran dan pengajaran. Jakarta Bumi Aksara

Ridwan, S. H. (2007). Pengantar statistika untuk penelitian, Bandung: Alfabeta.

Robbin. S.P. (2003). Perilaku organisasi. Jakarta PT. Indeks

Sanjaya, W. (2008). Kurikulum dan pembelajaran teori dan praktik pengembangan kurikulum tingkat satuan; Pendidikan (KTSP), Jakarta Penerbit Kencana.

Shalahudin, M. (2001). Pengantar psikologi pendidikan. Surabaya Bina Ilmu

Slameto. (2010). Belajar dan faktor-faktor yang mempengaruhi. Jakarta: Bina Aksara.

Sudijono, A. (2011). Pengantar evaluasi pendidikan. Jakarta PT. Raja Grafindo Persada.Sugiyono. (2010). Metode penelitian kuantitatif kualitatif dan $R$ \& $D$. Bandung Penerbit Alfabeta.

Suparman. (2014). Aplikasi komputer dalam penyusunan karya ilmiah. Jakarta: Pustaka Mandiri.

Sutjpto. (2001). Media pembelajaran manual dan digital. Bogor. Ghalia Indonesia.

Syah, M. (2001). Psikologi belajar. Jakarta PT. Logos Wacana Ilmu

Winardi. (2002). Teori motivasi belajar. Jakarta: PT. Gramedia

Winkel, W.S. (2004). Psikologi pendidikan dan evaluasi belajar. Jakarta Penerbit Gramedia. 